\title{
Molecular structure and IR spectra of butyl nitrates
}

\author{
(C) Daniil L. Egorov, ${ }^{+}$and Grigory M. Khrapkovsky* \\ Department of Intellectual Systems and Information Resources Management. Kazan National Research \\ Technological University. K. Marx St., 68. Kazan 420015. Republic of Tatarstan. Russia. \\ Phone: +7 (843) 231-42-53. E-mail: egorovdl2015@yandex.ru
}

\begin{abstract}
*Supervising author; ${ }^{+}$Corresponding author
Keywords: quantum-chemical calculation, molecular structure, vibration frequencies, butyl nitrates, Gaussian.
\end{abstract}

\begin{abstract}
The article is devoted to the description of using of two density functional methods B3LYP/6$31+\mathrm{G}(2 \mathrm{df}, \mathrm{p})$ and $w B 97 \mathrm{X} / \mathrm{Def} \mathrm{TZVPP}$, the geometric parameters and vibration frequencies of the $\mathrm{CONO}_{2}$ group, as well as the enthalpy of formation and dissociation energy of the $\mathrm{O}-\mathrm{NO}_{2}$ bond in the molecules of isomeric butyl nitrates (butyl nitrate, 2-butyl nitrate, isobutyl nitrate, tert-butyl nitrate) are determined. The authors show that the observed changes in the geometric parameters of the $\mathrm{CONO}_{2}$ group in the series of compounds studied are insignificant. According to the B3LYP method, they are $4.1 \mathrm{pm}$ for the $\mathrm{C}-\mathrm{O}$ bond, 0.7 $\mathrm{pm}$ for the $\mathrm{O}-\mathrm{NO}_{2}$ bond, and about 1 degree for the $\mathrm{ONO}$ angle. Another method used in this work (wB97X) predicts similar values of changes in the series. At the same time, the results of calculation make it possible to reliably distinguish, by the value of the geometric parameters, the nitrate groups attached to the primary secondary and tertiary carbon atoms, respectively. It is noted that the highest values of enthalpies of formation and energies (enthalpies) of dissociation are observed for compounds in which nitrate groups are attached to the primary carbon atom. The correlation dependences in the change in the enthalpies of formation of compounds and radicals, which are formed upon homolytic cleavage of the $\mathrm{O}-\mathrm{NO}_{2}$ bond, have been revealed. The tendencies of change in the series convey both methods used in the work in the same way. However, a comparison of the results with the available experimental data on the kinetics of thermal decomposition of the studied aliphatic nitrates shows that the most reliable estimates are the wB97X/Def2TZVPP method. The calculated values obtained on the basis of another B3LYP method used in the work are underestimated, by about 3-4 kcal/mol. It was found that of the stretching vibrations of the $\mathrm{CONO}_{2}$ group, only asymmetric vibrations of $\mathrm{N}-\mathrm{O}$ are characteristic.
\end{abstract}

\section{References}

[1] G.M. Khrapkovskii, G.N. Marchenko A.G. Shamov. The effect of molecular structure on the kinetic parameters of monomolecular decomposition of C- and O-nitrocompounds. Kazan. FAN. 1997. 224p. (russian)

[2] B.A. Lur'e, B.S. Svetlov. Kinetic characteristics of the primary stage of thermal decomposition of organic nitrates. Kinetics and catalysis. 1994. Vol.35. No.2. P.165-175. (russian)

[3] G.M. Khrapkovskii, T.F. Shamsutdinov, D.V. Chachkov, A.G. Shamov. Energy of the $\mathrm{O}-\mathrm{NO}_{2}$ bond dissociation and the mechanism of the gas-phase monomolecular decomposition of aliphatic alcohol nitroesters. J. Mol. Struct: THEOCHEM. 2004. Vol.686. Iss.1-3. P.185-192.

[4] D.L. Egorov, E.A. Mazilov, E.V. Ogurtsova, T.F. Shamsutdinov, A.G. Shamov, G.M. Khrapkovskii Effect of molecular structure on the strength of $\mathrm{O}-\mathrm{NO}_{2}$ in the series of aliphatic nitrates $\mathrm{C}_{1}-\mathrm{C}_{4}$. Bulletin of the Kazan Technological University. 2011. No.13. P.12-16. (russian)

[5] G.M. Khrapkovskii, A.G. Shamov, G.A. Shamov, V.A. Shlyapochnikov. Relationship between the kinetic characteristics of the gas-phase radical decomposition of nitro compounds with their molecular structure. Russian chemical journal. 1997. Vol.42. No.2. P.478. (russian)

[6] G.M. Khrapkovskii, D.D. Sharipov, A.G. Shamov, D.L. Egorov, D.V. Chachkov, Nguyen Van B., R.V. Tsyshevsky Theoretical study of substituents effect on $\mathrm{C}-\mathrm{NO}_{2}$ bond strength in mono substituted nitrobenzenes. Computational and Theoretical Chemistry. 2013. Vol.1017. P.7-13.

[7] D.L. Egorov, D.V. Chachkov, R. V. Tsyshevsky, A.G. Shamov, G.M. Khrapkovskii. Activation energy of halogennitroalkanes radical decay. Bulletin of the Kazan Technological University. 2010. No.9. P.5762. (russian) 
[8] D.V. Chachkov, D.L. Egorov, E. V. Nikolaeva, A.G. Shamov, G.M. Khrapkovskii. Theoretical study of competitive gas-phase decomposition mechanisms of nitroarenes with hydrogen-containing substituents: 3. Influence of molecular structure on the geometry transition state and activation enthalpy of reaction of intramolecular hydrogen transfer. Bulletin of the Kazan Technological University. 2010. No.9. P.44-49. (russian)

[9] R.V. Tsyshevsky, D.L. Egorov, I.V. Aristov, A.G. Shamov, G.M. Khrapkovskii. Structure of the transition state and kinetic parameters of radical decomposition nitromethane. Bulletin of the Kazan Technological University. 2012. Vol.15. No.4. P.28-31. (russian)

[10] D.D. Sharipov, D.L. Egorov, D.V. Chachkov, A.G. Shamov, G.M. Khrapkovskii. Theoretical study of competitive gas-phase decomposition mechanisms of nitroarenes with hydrogen-containing substituents: 1. Influence of molecular structure on durability of communication $\mathrm{C}-\mathrm{NO}_{2}$ and energy of activation of radical disintegration. Bulletin of the Kazan Technological University. 2010. No.7. P.4552. (russian)

[11] D.D. Sharipov, D.L. Egorov, D.V. Chachkov. Formation enthalpies and energies of dissociation bonds $\mathrm{C}-\mathrm{NO}_{2}$ in the series of nitrobenzene derivatives. Butlerov Communications. 2008. Vol.14. No.5. P.5259. ROI: jbc-02/8-14-5-52

[12] D.D. Sharipov, D.L. Egorov, D.V. Chachkov. Molecular structure of nitrobenzene and a series of its monofunctional derivatives in gaseous state. Butlerov Communications. 2008. Vol.14. No.5. P.46-51. ROI: jbc-02/8-14-5-46

[13] D.L. Egorov, A.G. Shamov, G.M. Khrapkovskii. Enthalpies of formation and dissociation energies of $\mathrm{O}-\mathrm{NO}_{2}$ in a series fluorinated, chlorinated and fluorine-chlorinated derivatives of methyl nitrate. Bulletin of the Kazan Technological University. 2012. Vol.15. No.10. P.7-10. (russian)

[14] R.V. Tsyshevsky, D.L. Egorov, E.V. Nemtareva, A.G. Shamov, G.M. Khrapkovskii. Structure of the transition state and kinetic parameters of radical decomposition of methyl nitrate. Bulletin of the Kazan Technological University. 2012. Vol.15. No.7. P.33-36. (russian)

[15] E.V. Nemtareva, E.A. Mazilov, E.V. Nikolaeva, A.G. Shamov, G.M. Khrapkovskii. Quantum-chemical study of the molecular structure and mechanisms of the gas-phase decomposition of ethyl nitrite and ethyl nitrate. Bulletin of the Kazan Technological University. 2011. No.23. P.20-26. (russian)

[16] Nguyen Van B., R.V. Tsyshevsky, G.M. Khrapkovskii. Theoretical definition of geometric parameters and charges on atoms in molecules of cation and anion of ethyl nitrate radicals. Bulletin of the Kazan Technological University. 2012. Vol.15. No.7. P.21-25. (russian)

[17] Gaussian 16, Revision A.03, M.J. Frisch, G.W. Trucks, H.B. Schlegel, G.E. Scuseria, M.A. Robb, J.R. Cheeseman, G. Scalmani, V. Barone, G.A. Petersson, H. Nakatsuji, X. Li, M. Caricato, A.V. Marenich, J. Bloino, B.G. Janesko, R. Gomperts, B. Mennucci, H.P. Hratchian, J.V. Ortiz, A.F. Izmaylov, J.L. Sonnenberg, D. Williams-Young, F. Ding, F. Lipparini, F. Egidi, J. Goings, B. Peng, A. Petrone, T. Henderson, D. Ranasinghe, V.G. Zakrzewski, J. Gao, N. Rega, G. Zheng, W. Liang, M. Hada, M. Ehara, K. Toyota, R. Fukuda, J. Hasegawa, M. Ishida, T. Nakajima, Y. Honda, O. Kitao, H. Nakai, T. Vreven, K. Throssell, J.A. Montgomery, Jr., J.E. Peralta, F. Ogliaro, M.J. Bearpark, J.J. Heyd, E.N. Brothers, K.N. Kudin, V.N. Staroverov, T.A. Keith, R. Kobayashi, J. Normand, K. Raghavachari, A.P. Rendell, J.C. Burant, S.S. Iyengar, J. Tomasi, M. Cossi, J.M. Millam, M. Klene, C. Adamo, R. Cammi, J.W. Ochterski, R.L. Martin, K. Morokuma, O. Farkas, J.B. Foresman, and D.J. Fox. Gaussian, Inc., Wallingford CT. 2016.

[18] D.L. Egorov, G.M. Khrapkovskii, A.G. Shamov. Program CalcTDFunc for calculating thermodynamic parameters based on calculation results in Gaussian. Bulletin of the Technological University. 2019. Vol.22. No.6. P.5-7. (russian)

[19] Gauss View, Version 5, Roy Dennington, Todd A. Keith, and John M. Millam, Semichem Inc., Shawnee Mission, KS, 2008.

[20] E.A. Mazilov, E.V. Ogurtsova, A.G. Shamov, G.M. Khrapkovskii Theoretical study of the competition between various mechanisms of gas-phase decomposition in the series of primary N-nitramines. Russian Journal of Applied Chemistry. 2009. Vol.82. No.10. P.1792-1798.

[21] E.A. Mazilov, E.V. Nikolaeva, A.G. Shamov, G.M. Khrapkovskii A theoretical study of the mechanism of the gas-phase unimolecular decomposition of $N$-methylnitramine. Mendeleev Communications. 2007. Vol.17. No.6. P.359-361.

[22] E.A. Mazilov, D.V. Chachkov, A.G. Shamov, G.M. Khrapkovskii Molecular structure and mechanisms of unimonomolecular decomposition of primary $N$-nitramines. Russian Journal of General Chemistry. 2009. Vol.79. No.3. P.414-427. 